\title{
Prognosing the sex of adults of Amblyomma auricularium through evaluating the biological parameters of engorged nymphs
}

\author{
Prognóstico do sexo dos adultos de Amblyomma auricularium através da avaliação de parâmetros \\ biológicos de ninfas ingurgitadas
}

\author{
Michele da Costa Pinheiro ${ }^{\mathrm{F}^{*}}$ Iwine Joyce Barbosa de Sá ${ }^{\mathrm{I}}$ Carla Carolina Dias Uzedo Ribeiro ${ }^{\mathrm{I}}$ \\ Camila Dantas Martins ${ }^{\text {II }}$ Vanessa de Almeida Raia ${ }^{\text {III }}$ Kátia Maria Famadas ${ }^{\text {IV }}$
}

\section{ABSTRACT}

Maintaining tick colonies under laboratory condition, as well as carrying out experimental studies on these arthropods may be more successful with better knowledge of some basic biological parameters. In this study, we evaluated how the weight, engorgement period and premolt period of Amblyomma auricularium nymphs $(N=600)$ correlated with the sex of the adults that subsequently emerged. The experiment was carried out in the W.O. Neitz Parasitological Research Station, Ixodology Laboratory of the Department of Animal Parasitology, Federal Rural University of Rio de Janeiro, located in Seropédica, state of Rio de Janeiro. The average weight of the nymphs was $5.1 \pm 1.51 \mathrm{mg}$ among those that originated males and $8.2 \pm 2.5 \mathrm{mg}$ among those that originated females. The engorgement period for the nymphs that originated males was $8.3 \pm 1.5$ days while it was longer for the nymphs that originated females, with an average of $8.8 \pm 1.8$ days to complete their diet. The premolt period was shorter for nymphs that originated males $(17.2 \pm 0.93$ days $)$ than for nymphs that originated females (17.7 \pm 1.00 days). Despite an area of overlapping between the weights of engorged nymphs that originated adult males and females, this is the most reliable parameter for predicting the sex of adults of A. auricularium.

Key words: relationship of weight $X$ sex, engorgement period, premolt period, Neotropical ticks, experimental infestations.

\section{RESUMO}

Para melhor gerenciamento e otimização da manutenção de colônias e experimentos com carrapatos ixodídeos, realizou-se este estudo avaliando a relação do peso, período parasitário e período de pré-ecdise de ninfas de

\begin{abstract}
Amblyomma auricularium $(N=600)$ com o sexo dos adultos emergidos. O trabalho foi realizado no Laboratório de Ixodologia do Departamento de Parasitologia Animal da Universidade Federal Rural do Rio de Janeiro. O peso médio das ninfas foi de 5,1 $\pm 1,51 \mathrm{mg}$ naquelas que originaram machos $e$ de $8,2 \pm 2,5 \mathrm{mg}$ naquelas que deram origem a fêmeas. Em relação ao período de ingurgitamento, o das ninfas que originaram machos foi de 8,3 1,5 dias, enquanto as ninfas que originaram fêmeas demoraram em média 8,8 1,8dias para completar sua alimentação. Já o período de pré-ecdise foi mais curto para ninfas que originaram machos, 17,2 $\pm 0,93$ dias, em relação às ninfas

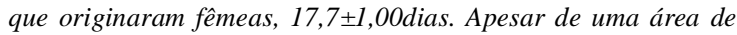
sobreposição dos pesos de ninfas ingurgitadas que originaram adultos machos e fêmeas, esse parâmetro é o mais confiável para o prognóstico do sexo dos adultos de A. auricularium.
\end{abstract}

Palavras-chave: relação peso X sexo, período de ingurgitamento, período de pré-ecdise, fase não parasitária, carrapatos neotropicais.

\section{INTRODUCTION}

To establish colonies of arthropods in a laboratory, adequate equipment, personnel qualified to deal with these arthropods and, especially, biological knowledge of the species that will be kept in the laboratory is required (CANÇADO et al., 2007). Through knowledge of species biology, colony maintenance and experiments that are designed using ixodid ticks may be improved.

'Programa de Pós-graduação em Ciências Veterinárias, Universidade Federal Rural do Rio de Janeiro (UFRRJ), Seropédica, RJ, Brasil

E-mail: michelezootec@gmail.com. *Autor para correspondência.

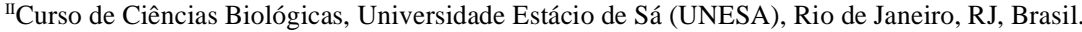

"IILaboratório de Doenças Parasitárias, UFRRJ, Seropédica, RJ, Brasil.

${ }^{\text {IV }}$ Departamento de Parasitologia Animal, UFRRJ, Seropédica, RJ, Brasil. 
The biological parameters of nymphs have previously been evaluated with the aim of determining the sex of adults of some species of Neotropical ticks. The weight of engorged nymphs, engorgement period and premolt period have been the most commonly used parameters, as can be seen in relation to Amblyomma cajennense (FABRICIUS, 1787) (OLIVIERI et al., 1986; BARBIERI et al., 2001; PINTER et al., 2002), Amblyomma tigrinum (Kock, 1844) (LABRUNA et al., 2002), Amblyomma triste (Kock, 1844) (LABRUNA et al., 2003), Haemaphysalis leporispalustris (Packard, 1869) (FREITAS et al., 2000) and Rhipicephalus sanguineus (Latreile, 1806) (BARBIERI et al., 2003). It is important to prognose the sex of adult specimens while they are still at the nymphal stage, in order to optimize experiments under laboratory conditions, especially those that require previous determination.

Amblyomma auricularium (Conil, 1878) has been recorded in Neotropical and Nearctic regions from the southern United States to Patagonia, in Argentina (LORD \& DAY, 2000; GUGLIELMONE et al., 2003; KERIANS, 2003). Adults of $\boldsymbol{A}$. auricularium have been found parasitizing mainly armadillos (Dasypodidae) (VENZAL et al., 2002; GUGLIELMONE et al. 2003; 2006; BERMUDÉZ et al., 2010) and, occasionally, other domestic or wild mammals (ALLAN et al., 2001; GUGLIELMONE et al., 2003; DANTAS-TORRES et al., 2010). Immature stages have been recorded as parasitizing armadillos, marsupials, rodents and domestic dogs (GUGLIELMONE et al., 2003; BERMUDÉZ et al., 2010; DANTAS-TORRES et al., 2010; EVANS et al., 2000; OLEGÁRIO et al., 2006; SZABÓ et al., 2007). Despite the wide geographical distribution, there are few studies on the bioecology of this ixodid.

The first study on the biology of $\boldsymbol{A}$. auricularium was carried out by FACCINI et al. (2010), under laboratory conditions. They described the life cycle of these ticks using rabbits as experimental hosts. In the present study, we evaluated how the weight, engorgement period and premolt periods of A. auricularium nymphs correlated with the sex of the adults that subsequently emerged, as a tool for planning colonies of A. auricularium.

\section{MATERIALS AND METHODS}

All the specimens were kept in an incubator set at a temperature of $27 \pm 1^{\circ} \mathrm{C}$ and relative humidity (RH) of $80 \pm 10 \%$, in $24 \mathrm{~h}$ darkness. Unfed nymphs of $\boldsymbol{A}$. auricularium, aged 15 to 20 days, were fed on four tick-naive rabbits (Oryctolagus cuniculus). The infested rabbits were kept in individual wired cages $(60 \times 60 \times 60 \mathrm{~cm})$ in a ventilated room under a natural light regime, and were fed with commercial food pellets and water ad libitum. The infestation was produced as described by NEITZ et al. (1971), such that the specimens were administered inside muslin sleeves that were glued using non-toxic glue (Unna's paste) to the base of the rabbits' ears. The rabbits were each infested with 300 nymphs of $\boldsymbol{A}$. auricularium, and thus a total of 1200 nymph specimens were administered.

When the engorged nymphs dropped off, they were collected every day, until the last specimen had been recovered. They were then washed in $1 \%$ hypochlorite and dried on paper towels. Groups of 50 specimens each were formed every day, with the exception of the first day of recovery, when only eight specimens were recovered. In this manner, 12 sample groups were obtained. Each specimen was weighed on an electronic analytical balance and was individually housed in a properly identified glass vial, corked with cotton wool, and was maintained under controlled laboratory conditions until the adult emerged. The adults were sexed by observing the dorsal shield (EVANS, 1992). The weights of the engorged nymphs and the length of the premolt period (the period between collecting the engorged nymphs and emergence of the adults) were analyzed using the Mann-Whitney test. Data on the engorgement period (the period between the day of infestation and the day of recovery of the engorged nymph) were evaluated by means of analysis of variance (ANOVA) and the Tukey-Kramer test with a significance level of $5 \%$.

\section{RESULTS}

The mortality rate among the 600 nymphs used in the experiment was $3.5 \%$. Table 1 shows the mean values and standard deviation of the parameters of the engorged $\boldsymbol{A}$. auricularium nymphs that were analyzed. The weight range of the engorged nymphs was 1.5 to $13.2 \mathrm{mg}$ (Table 1). The average weight of those that originated females was higher than the weight of those that originated males $(\mathrm{P}<0.05)$, with means and standard deviations of $8.2 \pm 2.48$ and $5.1 \pm 1.51$, respectively. Of the 579 nymphs that reached adulthood, $266(46 \%)$ originated males and $313(54 \%)$ originated females. The percentages of the nymphs that originated males and females recovered per day can be seen in figure 1 . The length of the engorgement period of the nymphs ranged from 7 to 12days, with a mean of $8.8 \pm 1.8$ days for nymphs that originated females and $8.30 \pm 1.5$ days for males $(\mathrm{P}<0.05)$ (Table 1). 
Table 1 - Mean values and standard deviations of the biological parameters of engorged nymphs of Amblyomma auricularium as a predictor of sex adults under controlled conditions $\left(27 \pm 1^{\circ} \mathrm{C}, 80 \pm 10 \% \mathrm{RH}\right.$, scotophase).

\begin{tabular}{|c|c|c|c|c|}
\hline Parameters & & Total & Males & Females \\
\hline \multirow[t]{3}{*}{ Weight (mg) } & $\mathrm{X} \pm \sigma$ & $6.7 \pm 2.59$ & $5.1^{\mathrm{a}} \pm 1.51$ & $8.2^{\mathrm{b}} \pm 2.48$ \\
\hline & (range) & $(1.5-13.2)$ & $(1.5-8.8)$ & $(2.5-13.2)$ \\
\hline & $\mathrm{n}$ & 579 & 266 & 313 \\
\hline \multirow[t]{3}{*}{ Engorgement period (days) } & $\mathrm{X} \pm \sigma$ & $8.6=1.68$ & $8.3^{\mathrm{a}} \pm 1.5$ & $8.8^{\mathrm{b}} \pm 1.8$ \\
\hline & (range) & $(7-12)$ & $(7-12)$ & $(7-12)$ \\
\hline & $\mathrm{n}$ & 579 & 266 & 313 \\
\hline \multirow[t]{3}{*}{ Premolt period (days) } & $\mathrm{X} \pm \sigma$ & $17.4 \pm 1.00$ & $17.2^{\mathrm{a}} \pm 0.93$ & $17.7^{\mathrm{b}} \pm 1.00$ \\
\hline & (range) & $(15-20)$ & $(15-20)$ & $(15-20)$ \\
\hline & $\mathbf{n}$ & 579 & 266 & 313 \\
\hline
\end{tabular}

Means followed by different letters in the same line are significantly different $(\mathrm{P}<0.05)$.

The premolt period was significantly $(\mathrm{P}<0.05)$ shorter for the nymphs that originated males (mean of 17.2 \pm 0.93 days) than for the nymphs that originated females (mean of $17.7 \pm 1.00$ days), both ranging from 15 to 20 days (Table 1).

\section{DISCUSSION}

In this study, we used engorged nymphs of A. auricularium that were collected between the $7^{\text {th }}$ and $12^{\text {th }}$ day after infestation of four tick-naive rabbits experimentally infested. Some authors who used the same technique recovered engorged nymphs of $\boldsymbol{H}$. leporispalustris between the sixth and ninth days after infestation (FREITAS et al., 2000), while others recovered nymphs of $\boldsymbol{R}$. sanguineus on the third day after infestation (BARBIERI et al., 2003), all with weight lower than what was observed in $\boldsymbol{A}$. auricularium this study.

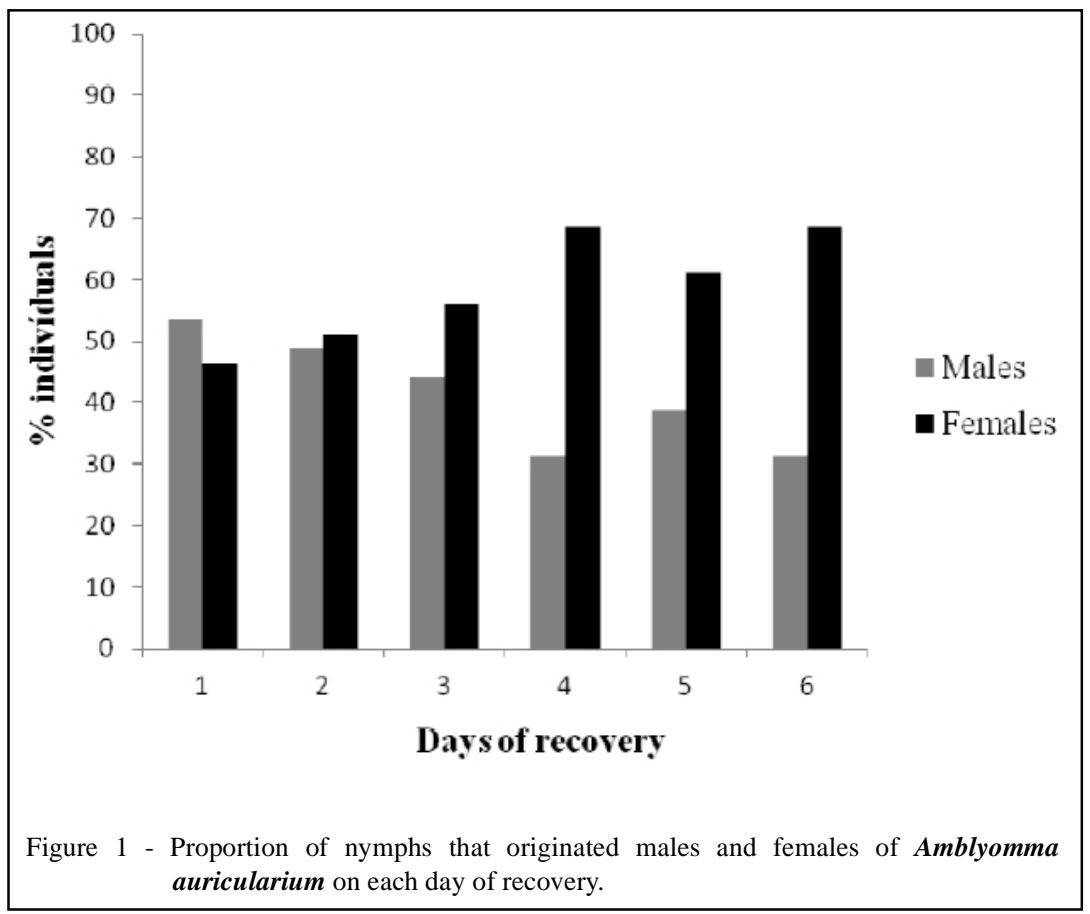

Ciência Rural, v.43, n.4, abr 2013. 
Significant difference $\quad(\mathrm{P}<0.05) \quad$ was observed between the mean weights of the experimental groups, which was similar to what was found by LABRUNA et al. (2002) for A tigrinum. When engorged nymphs of $\boldsymbol{A}$. auricularium were divided into frequency classes (Figure 2), according to the weight and sex of the emerging adults, it was observed that both males and females originated from nymphs that weighed between $2.5 \mathrm{mg}$ and $8.9 \mathrm{mg}$. A higher percentage of the nymphs that originated males were concentrated in groups of lower weight, while nymphs that originated females were concentrated in higher weight classes. Engorged nymphs of $\boldsymbol{A}$. auricularium weighing less than $2.5 \mathrm{mg}$ solely originated males, while nymphs weighing more than $8.9 \mathrm{mg}$ solely originated females.

In relation to A. cajennense (OLIVIERI et al., 1986, BARBIERI et al., 2001) and $\boldsymbol{R}$. sanguineus (BARBIERI et al., 2003), overlapping weight classes between nymphs that originated males and females were also observed. For these species, this parameter was considered impractical for predicting the sex of the adult form. However, for A. auricularium, despite the wide range of overlapping weights, this parameter should not be discarded given that the nymphs weighing less than $2.5 \mathrm{mg}$ and more than $8.9 \mathrm{mg}$ only originated adults of one sex.

According to HU \& ROWLEY (2000), females are generally heavier than males because they need more nutrients from the host's blood for their continued development. OLIVER (1977) affirmed that the feeding behavior of nymphs may be affected by sex chromosomes. As a result, nymphs that develop into females may be more aggressive when feeding, in relation to the nymphs that originate males.

It has been documented in the literature that periods of engorgement and premolt regulate the emergence of early males. PRATA et al. (1998) observed a higher percentage of males among the nymphs collected on the first days of recovery. BARBIERI et al. (2001) observed that the period of engorgement was longer for nymphs of $A$. cajennense that originated females, because $61 \%$ of the nymphs that originated males engorged in less than four days, while $78 \%$ of the nymphs that originated females took more than five days to complete engorgement.

In relation to engorged nymphs of $\boldsymbol{H}$. leporispalustris, FREITAS et al. (2000) observed that a higher percentage of the nymphs recovered in the early days originated males. By the day that was the mode for the numbers of nymphs dropping, the proportions of nymphs that originated males and females had become equal, and then a higher number of nymphs that originated females was observed on the last days of recovery. A similar pattern was observed among the nymphs recovered from $\boldsymbol{A}$. auricularium in the present study (Figure 1): on the first days of recovery, there were greater numbers of nymphs that originated males, while the last days of recovery produced greater numbers of nymphs that originated females of A. auricularium.

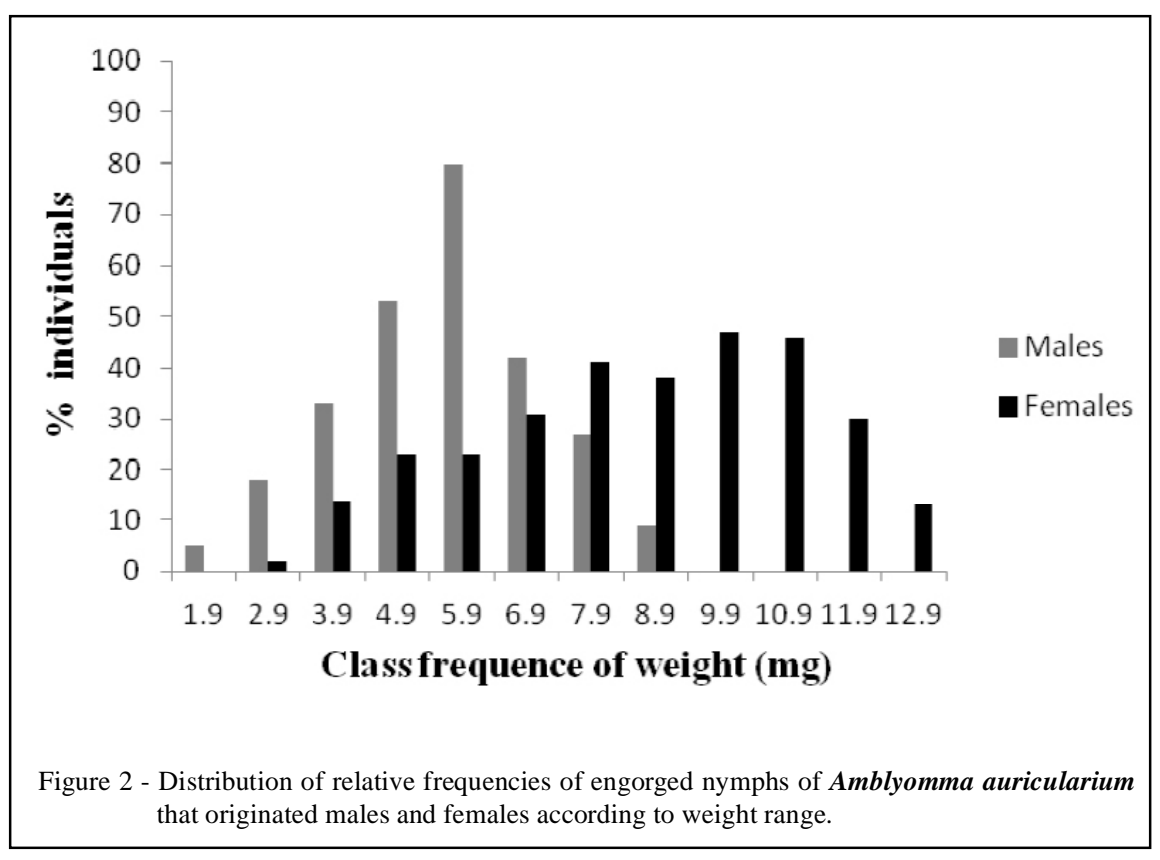

Ciência Rural, v.43, n.4, abr, 2013. 
Regarding the premolt period of $\boldsymbol{A}$. cajennense, BARBIERI et al. (2001) observed that it was shorter for nymphs that originated males, in the same way as seen in the present study. Despite the statistical difference observed, the results were very close to being biologically similar.

RECHAV \& KNIGHT (1981) stated that by means of the lengths of the engorgement and premolt periods, early emergence of males is regulated such that when one of the periods is on average shorter for nymphs that originate males, the other is similar for the two sexes.

\section{CONCLUSION}

Based on our analysis, despite the statistical significance of the data, it was found not to be possible to achieve accurate prediction of the sex of the adults based on the lengths of the premolt and engorgement periods. These factors could only be used in cases in which there was a higher prevalence of one sex over the other.

Despite the large area of overlap of the weights of engorged nymphs, between those that resulted in adult males and those that resulted in females, this parameter can be used to predict the sex of the adults at the extremities of the weight range, given that these weight ranges originated adults of a single sex.

\section{BIOETHICS AND BIOSSECURITY COMMITTEE APPROVAL}

The present study was approved by Ethics Committee on Use of Animals, Universidade Federal Rural do Rio de Janeiro/ COMEP, under process number 160/2011.

\section{REFERENCES}

ALLAN, S.A. et al. Ixodid ticks on white-tailed deer and feral swine in Florida. Journal Vector Ecology, v.26, p.93-102, 2001.

BARBIERI, F.S. et al. Avaliação do peso e de parâmetros biológicos de ninfas ingurgitadas de Amblyomma cajennense (Fabricius, 1787) (Acari: Ixodidae) como prognóstico do sexo dos adultos. Revista Brasileira de Parasitologia Veterinária, v.10, p.83-86, 2001.

BARBIERI, F.S. et al. Morfometria e biologia das ninfas ingurgitadas de Rhipicephalus sanguineus (Latreile, 1806) (Acari: Ixodidae) como prognóstico do sexo dos adultos. Revista Brasileira de Parasitologia Veterinária, v.12, p.159-163, 2003.

CANÇADO, P.H.D. et al. Influência do comportamento gregário nos processos de muda de Rhipicephalus sanguineus (Latreille, 1806) (Acari: Ixodidae), em condições laboratoriais. Revista Brasileira de Parasitologia Veterinária, v.16, p.205-210, 2007.
Available from: <http://www.scielo.br/scielo.php?pid=S198429612007000400005\&script=sci_arttext $>$. Accessed: Jun. 25, 2012. doi: 10.1590/S1984-29612007000400005.

DANTAS-TORRES, F. et al. Ticks infesting wildlife species in Northeastern Brazil with new host and locality records. Journal Medical Entomology, v.47, p.1243-1246, 2010. Available from: <http://www.bioone.org/doi/abs/10.1603/ME10156>. Accessed: Jun. 25, 2012. doi: 10.1603/ME10156.

EVANS, G.O. Principles of acarology. Wallingford, Oxon: CAB International, 1992. 563p.

EVANS, D.E. et al. A review of the ticks (Acari: Ixodidae) of Brazil, their hosts and geographic distribution - 1. The state of Rio Grande do Sul, Southern Brazil. Memórias do Instituto Oswaldo Cruz, v.95, p.453-470, 2000. Available from: <http://www.scielo. $\mathrm{br} / \mathrm{scielo}$.php?pid=S0074-02762000000400003\& $\mathrm{script}=\mathrm{sci}$ arttext>. Accessed: Jun. 25, 2012. doi: 10.1590/S007402762000000400003 .

FACCINI, J.L.H. et al. The life cycle of Amblyomma auricularium (Acari: Ixodidae) using rabbits (Oryctolagus cuniculus) as experimental host. Experimental and Applied Acarology, v.50, p.71-77, 2010. Available from: <http://link.springer.com/ article/10.1007\%2Fs10493-009-9281-z?LI=true>. Accessed: Jun. 25, 2012. doi: 10.1007/s10493-009-9281-z.

FREITAS, L.H.T. et al. Relação entre o peso e o número de larvas e ninfas ingurgitadas e entre o período de ingurgitamento ninfal e o sexo dos adultos de Haemaphysalis leporispalustris (Packard, 1869) (Acari: Ixodidae) em condições experimentais. Revista Brasileira de Zoociências, v.2, p.21-32, 2000.

GUGLIELMONE,A.A. et al. Hosts and distribution of Amblyomma auricularium (Conil, 1878) and Amblyomma pseudoconcolor Aragão, 1908 (Acari: Ixodidae). Experimental and Applied Acarology, v29, p.131-139, 2003. Available from: <http://link. springer.com/article/10.1023\%2FA\%3A1024251020035?LI=tr ue>. Accessed: Jun. 25, 2012. doi: 10.1023/A:1024251020035.

HU, R.; ROWLEY, W.A. Relationship between weights of the engorged nymphal stage and resultant sexes in Ixodes scapularis and Dermacentor variabilis (Acari: Ixodidae) ticks. Journal Medical Entomology, v.37, p.198-200, 2000. Available from: <http://www.ncbi.nlm.nih.gov/pubmed/15218928>. Accessed: Jun. 25, 2012. doi: 10.1603/0022-2585-37.1.198.

KEIRANS, J.E. Host and distribution of Amblyomma auricularium (Conil 1878) and Amblyomma pseudoconcolor Aragão, 1908 (Acari: Ixodidae). Experimental and Applied Acarology, v.29, p.131-139, 2003. Available from: <http://link. springer.com/article/10.1023\%2FA\%3A1024251020035? LI=tr ue\#>. Accessed: Jun. 25, 2012. doi: 10.1023/A:1024251020035.

LABRUNA, M.B. et al. Life-cycle and host specificity of Amblyomma tigrinum (Acari: Ixodidae) under laboratory conditions. Experimental and Applied Acarology, v.24, p.115125, 2002.

LABRUNA, M.B. et al. Life cycle and host specificity of Amblyomma triste (Acari: Ixodidae) under laboratory conditions. Experimental and Applied Acarology, v.30, p.305316, 2003. Available from: <http://www.ncbi.nlm.nih.gov/ pubmed/14756395>Accessed: Jun. 25, 2012. doi: 10.1023/B:AP PA.0000006514.02451.6d. 
LORD, C.C.; DAY, J.F. First record of Amblyomma auricularium (Acari:Ixodidae) in the United States. Journal MedicalEntomology, v.37, p.977-978, 2000. Available from: 〈http://www.bioone.org/doi/ abs/10.1603/0022-2585-37.6.977?journalCode=ment $>$. Accessed: Jun. 25, 2012. doi: 10.1603/0022-2585-37.6.977.

NEITZ, W.O. et al. Laboratory investigations on the karoo paralysis tick (Ixodes rubicundus Neumann, 1904). Onderstepoort Journal Veterinary Research, v.38, p.215-224, 1971.

OLEGÁRIO, M.M.M. et al. Carrapatos em áreas do cerrado brasileiro. Veterinária Notícias, v.12, p.39, 2006.

OLIVER Jr., J.H. Cytogenetics of mites and ticks. Annual Review Entomology, v.22, p.407-429,1977. Available from: <http://www.annualreviews.org/doi/abs/10.1146/annurev. en.22.010177.002203>. Accessed: Jun. 25, 2012. doi: $10.1146 / .22 .010177 .002203$.

OLIVIERI, J.A. et al. Correspondência entre o peso, período de pré-muda da metaninfa e o sexo do adulto em duas linhagens de Amblyomma cajennense (FABRICIUS, 1787) (Acarina: Ixodidae). Atas da Sociedade de Biologia do Rio de Janeiro, v.26, p.5-8, 1986.
PINTER, A. et al. The sex ratio of Amblyomma cajennense (Acari: Ixodidae) with notes on the male feeding period in the laboratory. Veterinary Parasitology, v.105, p.79-88, 2002. Available from: <http://www.sciencedirect.com/science/article/pii/ S0304401701006501>. Accessed: Jun. 25, 2012. doi: 10.1016/ S0304-4017(01)00650-1.

PRATA, M.C.A. et al. Relationship between weight and number of engorged Amblyomma cajennense larvae and nymphs (Fabricius, 1787) (Acari: Ixodidae ) in experimental infestations on rabbits. Revista Brasileira de Parasitologia Veterinária, v.7, p.107-111, 1998.

RECHAV, Y; KNIGHT, M.M. Life cycle in the laboratory and seasonal activity of the tick Rhipicephalus glabroscutatum (Acarina: Ixodidae). Journal of Parasitology, v.67, p.85-89, 1981.

SZABÓ, M.P.J. et al. Tick fauna from two locations in the Brazilian savannah. Experimental and Applied Acarology, v.43, p.73-84, 2007. Available from: <http://link.springer.com/ article/10.1007\%2Fs10493-007-9096-8?LI=true>. Accesed: Jun. 252012. doi: 10.1007/s10493-007-9096-8.

VENZAL, J.M. et al. First records of Amblyomma auricularium (Conil, 1878) and Amblyomma pseudoconcolor Aragão, 1908 (Acari: Ixodidae) from Uruguay. Systematic Applied Acarology, v.7, p.109-111, 2002. 